\title{
Improvement of transversal professional skills through cooperative work and group dynamics in the UPV Master's Degree in Energy Technologies for Sustainable Development (MUTEDS)
}

\author{
D. Alfonso-Solar ${ }^{\mathrm{a}}$, C. Vargas-Salgado ${ }^{\mathrm{a}}$, C. Montagud ${ }^{\mathrm{a}}$, J.M. Corberán ${ }^{\mathrm{a}}$

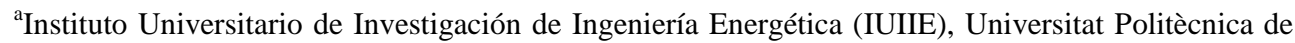 \\ València, Valencia, 46022, Spain, e-mail: daalso@iie.upv.es, web: http://www.iie.upv.es
}

\begin{abstract}
This article presents an updating of the structure, methodology and evaluation results after 4 years of teaching (courses 2015-2016, 2016-2017, 2017-18 and 2018-19) of a subject entitled Applied energy technology Project course belonging to MUTEDS (Master's Degree in Energy Technology for Sustainable Development) at the Universitat Politècnica de València).

The presented subject is mainly focused on the improvement of professional skills as multidisciplinary teamwork and leadership, lifelong learning, competitiveness, planning and managing of time and effective communication in English. To work these skills, students have to do the exercise of creating a company (including name and logo) where there are 4 -6 students randomly selected and with different roles; this company evaluates the technoeconomic and environmental feasibility of an energy project (related with energy efficiency and renewable energy sources in and specific location) during 8 technical sessions (in which roles change in each session), and present the project proposal in a public competitive event where the students vote for the best work according to their point of view. In parallel, transversal competences associated to the above mentioned professional skills and the academic quality of the reports are evaluated by the professors.
\end{abstract}

Keywords: professional skills, cooperative work, group dynamics 


\section{Introduction}

The implementation of the new educational framework of the Bologna Process has required a redesign and adaptation of the curriculum of bachelor and master degrees, based on skills or competences development (García Manjón, 2008). Within this context, it emerges a new concept of teaching and learning, which is centered on the student and whose objective is that students learn to learn. For that purpose, and according to (Pérez Gómez, 2007), it will be necessary to create situations of uncertainty and dynamic processes where the students put into practice their knowledge and skills. Therefore, a correct development of competences will involve the simulation of real situations that the students will find not only throughout their professional lives but also in their daily lives. In these situations they will apply their knowledge (learning further concepts/tools if necessary) to solve problems that may arise. It should also encourage cooperative work among students, which includes activities such as dialogue, debate, multidisciplinary and multilingual teamwork enriched by the contributions of others, respect for differences, listening, teamwork, etc. This in turn affects the teaching methodology, planning and evaluation (Yániz, 2008).

In this context, the Universitat Politècnica de València (UPV), launched the UPV Transversal Competences Institutional Project (which began as a pilot experience during the 2014/2015 academic year, being the beginning of year 2015/2016 its definitive implementation). It should be noted that its fundamental objective was to establish a strategy of systematic evaluation of transversal competences, defining in which subjects they are acquired and how they should be evaluated, as well as accrediting the acquisition of such competences.

The potential of varius active methodologies to enhance the development of transversal competences was analysed in (Robledo, 2015) from the students perspective, resulting the problem-based learning the most useful one, as it combines the acquisition of knowledge with the development of skills, attitudes and useful skills for the professional market; in addition, it is based on promoting the autonomous work of the students, who, organized in groups and tutored by a professor, should try to propose an effective solution to a problem which is characteristic of their professional profile.

This article presents the structure, methodology and evaluation results after 4 years of teaching (2015-2019) of a subject titled Applied energy technology - Project course (AETP) belonging to Master in Energy Technology for Sustainable Development (MUTEDS) at the Universitat Politècnica de València. The didactic techniques considered by professors to encourage participation and motivation of the student in class, the activities 
developed to promote the cooperative learning in a dynamic environment, as well as the transversal competences assessment and the impact on the results will be presented.

\section{Description of the subject}

\subsection{Background}

The subject under study in this article is framed in the first year of the master MUTEDS of the School of Industrial Engineers (ETSII) at the (UPV). The aim of the master (described in (Master in Energy, 2019)) is to provide its graduates with the necessary knowledge to address professional activity or research work in the energy sector, according to the needs of sustainable development, so improving efficiency and $\mathrm{CO}_{2}$ /energy savings, and limiting the environmental impact of the processes of generation, transmission and use of energy. The subjects of the master are organized in 3 modules: Module 1(mandatory subjects), Module 2 (optional subjects) and Module 3 (Master's Thesis).

The subject AETP is mandatory, so it is included in Module 1. All the subjects of Module 1 are taught in English to comply with student exchange agreements with foreign universities, such as the agreement signed with the KTH Royal Institute of Technology in Sweden, to obtain a double degree.

The objective of AETP is the realization of a practical teamwork exercise focused on the design of an energy system for a particular application. The exercise will consist of a project design focused on renewable energies and energy efficiency, and includes the creation of a team, the dynamics of teamwork with different roles, the different phases in the development of a project design, search and compilation of information, discussion and synthesis of possible solutions, and finally an open door "commercial" presentation to sell the project.

\subsection{Teaching methodology}

In the process of teaching and learning, there are a total of three main actors involved: the student or individual who will learn, the professor, and the subject contents.

As described in (Johnson, 2013), there are different models of teaching and learning that depend on the approach in which each of these actors fulfill its role.

The model of teaching and learning or teaching methodology used in the subject under study in the present work is a student-centered model. In this model the main actor is the student. The professor is a figure that provides the necessary tools for students to build their 
knowledge, helps on providing sources of information, answers general questions, refers to learning tools, etc., always trying to encourage students motivation. Therefore, within this model of learning, students search, organize, study and finally learn.

\subsection{Contents: Learning units}

The didactic units in which the subject is structured correspond to the phases of development of a project related to energy systems. Unit names and description are included in Fig.1.

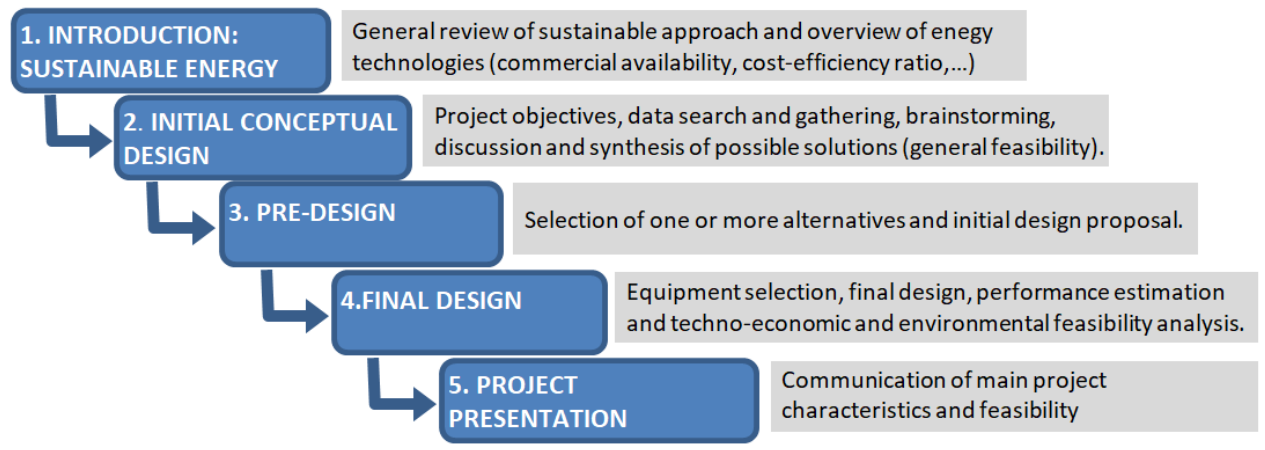

Fig. 1 AETP Didactic units and description

\subsection{Organization of the subject: group dynamics and planning}

The first day of class students are grouped into groups of 5-6 people randomly selected and assigned to a project type. There will be two types of projects: Project A (PA) consisting of the basic design of a single-family house with almost zero energy consumption; and Project $\mathrm{B}$ (PB), which consists of designing an off-grid polygeneration system (electricity, heat and cold) for a single application based on renewable energy, mainly solar, wind, biomass or any other feasible energy resource available in the location of the project.

Due to the fact that the subject belongs to Module 1 (mandatory subjects), the teaching language used is English, which is also higlhly convenient due to the high number of foreing students (25-30\% of students), that are either students coming from international exchange agreements of the master or ERASMUS students. This fact allows forming not only multidisciplinary but also multilingual and even multicultural teams. 
The random assignment of students in each group is performed in such a way that it is guaranteed that at least there is one foreign student inside each group. Analogously, gender differences are also covered so that there is at least one female per group.

For each type of project, there will be one responsible professor who guides students along the different stages of the process. Figure 1 graphically shows how the subject is organized.

Depending on the number of students enrolled, there should be a total of 8 groups (4 per project type).

Students choose a company name for their group as well as a logo that will represent both themselves and the philosophy of the project. Within each group, there will be several roles identified:

- LEADER: manages the group, takes final decisions in the different phases of the project, and is the spokesperson with the professor.

- SECRETARY: makes the summary of each session reflected in the portfolio that will be sent to the professor at the end of each week of class.

- STAFF: 3-4 people following the orders and providing support to the leader.

Regarding the planning, it is organized in sessions of about 2-3 hours. The first two sessions are mainly focused on introducing the subject, roles explanation, teams creation and project type assignment. After these initial sessions there should be, at least, 8 teamworking sessions: 6 sessions in which the roles are randomly assigned at the beginning of the semester for each team member (each student has a number inside the team and the role to be performed in each session is assigned according to a calendar for each student number), and 2 last sessions, in which the team has to decide who will be the leader and secretary in each session. All students have to perform each role at least once. The structure of the teamworking sessions is presented in the following:

- Introduction to the session (10 to about 20 minutes): first, the professor performs a summary of the previous session; then presents the current session objectives, recommended list of tasks to achieve them and recommended tools/methodologies.

- Teamwork by students in each group (it is recommended a session duration of about 180 minutes but 120 minutes is also feasible, so that the effective time dedicated to students teamwork would be at least 140 and 80 minutes respectivelly).

- Communication of results to the professor by the leader and resolution of main doubts (limited to 5 minutes per group) at the end of the session. It is important to limit this time to make the leader summarize and organize the session performance and priorize doubts. 
The last two sessions of the course are focused on the project oral presentation. Each team has to do two project presentations: on close-door presentation with the professor (for academic work evaluation purposes) and one open-door presentation (for competences evaluation purposes) to the whole class. In the last session, students will vote for the best project according to this open-door presentation (where time is also limited to 20-30 minutes, and in which all the students have to participate during 4-5 minutes).

\subsection{Evaluation}

The evaluation process has been developed taking into account the new educational framework of the Bologna Process. Therefore, the competences development by students is assessed. According to relevant bibliography (Pérez Gómez, 2007) the approach of teaching and learning based on competences development will be focused on students to construct their own mental models. It is important to emphasize that the development of competences requires to provide safe and comfortable environment in which students feel free and confident to try new concepts or technologies, make mistakes, feeding back, correct and so improve their competences and knowledge. Transversal competences evaluated in the subject are included in Table 1.

Table 1. Transversal competences evaluated in AETP

\begin{tabular}{|l|l|}
\hline Transversal competences & Description of key aspects in the subject \\
\hline $\begin{array}{l}\text { TC01: Comprenhension } \\
\text { and integration }\end{array}$ & $\begin{array}{l}\text { Understanding of the objective, data and results integration, consistency of } \\
\text { the methodology used and results. }\end{array}$ \\
\hline $\begin{array}{l}\text { TC05: Design and } \\
\text { project }\end{array}$ & Selection and use of available tools and design methodologies \\
\hline $\begin{array}{l}\text { TC06: Teamwork and } \\
\text { leadership }\end{array}$ & $\begin{array}{l}\text { Teamwork during the different class sessions: encouraging debate, synthesis } \\
\text { of solutions, innovation, etc. Leading/coordination of the group (for }\end{array}$ \\
\hline $\begin{array}{l}\text { TC11: Continuous } \\
\text { learning }\end{array}$ & $\begin{array}{l}\text { Continuous search for information, new methodologies, new design tools, } \\
\text { etc. }\end{array}$ \\
\hline $\begin{array}{l}\text { TC12:Planning and } \\
\text { time management }\end{array}$ & $\begin{array}{l}\text { Distributing and planning the tasks to be performed by the team. } \\
\text { Management capacity (for the role of secretary only). }\end{array}$ \\
\hline
\end{tabular}

As mentioned in (Cano-García, 2008), to conduct the competences acquisition assessment is necessary to sample executions of students and use observation as a strategy of systematic information collection. This process of collecting the information can be carried out by professors, by peers or by the students themselves (or all of them, in a $360^{\circ}$ assessment model). In order to be able to assess the transversal competences through active observation and systematic collection of information, there will be a continuous evaluation 
of the teaching-learning throughout the course (specially during the teamworking sessions). Key evaluation elements used during the teamworking sessions are:

- $\quad$ PORTFOLIO: consists of a paper document (also available in digital format) with main comments, decisions, notes,etc that stand for the work carried out in each teamworking session.

- ACTIVE OBSERVATION: professor has to observe the different teams during the 8 working sessions and make one/two interactions ( 5 minutes approximately) per team during each session (asking how they are addressing the objectives of the session, how is the work distribution and coordination inside the team,...)

- LEADER ORAL SUMMARY: at the end of each technical session, the leader communicates the professor a summary including the achieved goals and main difficulties/doubts found during the working session. The teacher may also ask for further clarifications of any aspect observed during the session or regarding the leader's summary.

The final qualification of the subject is obtained by means of the assessment methods and weights shown in Table 2. Each assessment method is evaluated numerically from 0 to 10 (in order to pass, student must have a mark equal or greater than 5).

Table 2. Subject assessment methods

\begin{tabular}{|l|l|c|}
\hline $\begin{array}{l}\text { ASSESSMENT } \\
\text { METHOD }\end{array}$ & Description & Weight \\
\hline ORAL EXAM & $\begin{array}{l}\text { Evaluation of oral communication quality, audiovisual support tools, } \\
\text { body language, timing, speakers coordination... } \\
\text { KEY EVALUATION ELEMENT: ORAL PRESENTATION }\end{array}$ & $40 \%$ \\
\hline $\begin{array}{l}\text { ACADEMIC } \\
\text { WORK }\end{array}$ & $\begin{array}{l}\text { Evaluation of quality/correctness of contents, coherence, scope, } \\
\text { structure and format,... } \\
\text { KEY EVALUATION ELEMENT: FINAL REPORT }\end{array}$ & $40 \%$ \\
\hline $\begin{array}{l}\text { TEAMWORKING } \\
\text { SESSIONS }\end{array}$ & $\begin{array}{l}\text { Evaluation of the team analysis and resolution of problems } \\
\text { work... } \\
\text { KEY EVALUATION ELEMENTS: PORTFOLIO + ACTIVE } \\
\text { OBSERVATION + LEADER ORAL SUMMARY }\end{array}$ & $20 \%$ \\
\hline
\end{tabular}

Regarding the evaluation process, there is rubric to evaluate students work in each of the assessment methods described in Table 2, which is provided to students since the very first day of the subject. The advantage of showing and using appropriate rubric headings is that it allows continuous self evaluation (for the students) which considerably improves the effective learning, as established in (Biggs, 2000). 
It must be noticed that transversal competences evaluation doesn't follow this weight distributions shown in Table 2. As their evaluation mostly takes place during the teamworking sessions (specially for TC06 and TC12, where it is the main element). Regarding the transversal competences assessment, UPV stablished a common scale (A, B, $\mathrm{C}, \mathrm{D})$ to indicate the level of development of each transversal competence. In this scale A means excellent (when mark is $\geq 9$, out of 10), B appropriate (from 7 to 9), C developing (from 5 to 7 ) and $\mathrm{D}$ (when mark is $<5$ ).

\section{Results}

Results about students assessment and tranversal competences evaluation is included in Fig. 2. It can be observed that results are very positive, looking at the different assessment methods in the last two courses, 2017-18 (Fig. 2.a) and 2018-19 (Fig. 2.b), qualifications are in the range 6 to 10, and final mark was in the range 7 to 10. Taking a look at the evolution of the final mark during three consecutive years, as shown in Fig.2.c, it can be concluded that values are very close, being a slight increase in the average final mark from a value of 8.65 (course 2016-17) to 9.0 (course 2018-19).
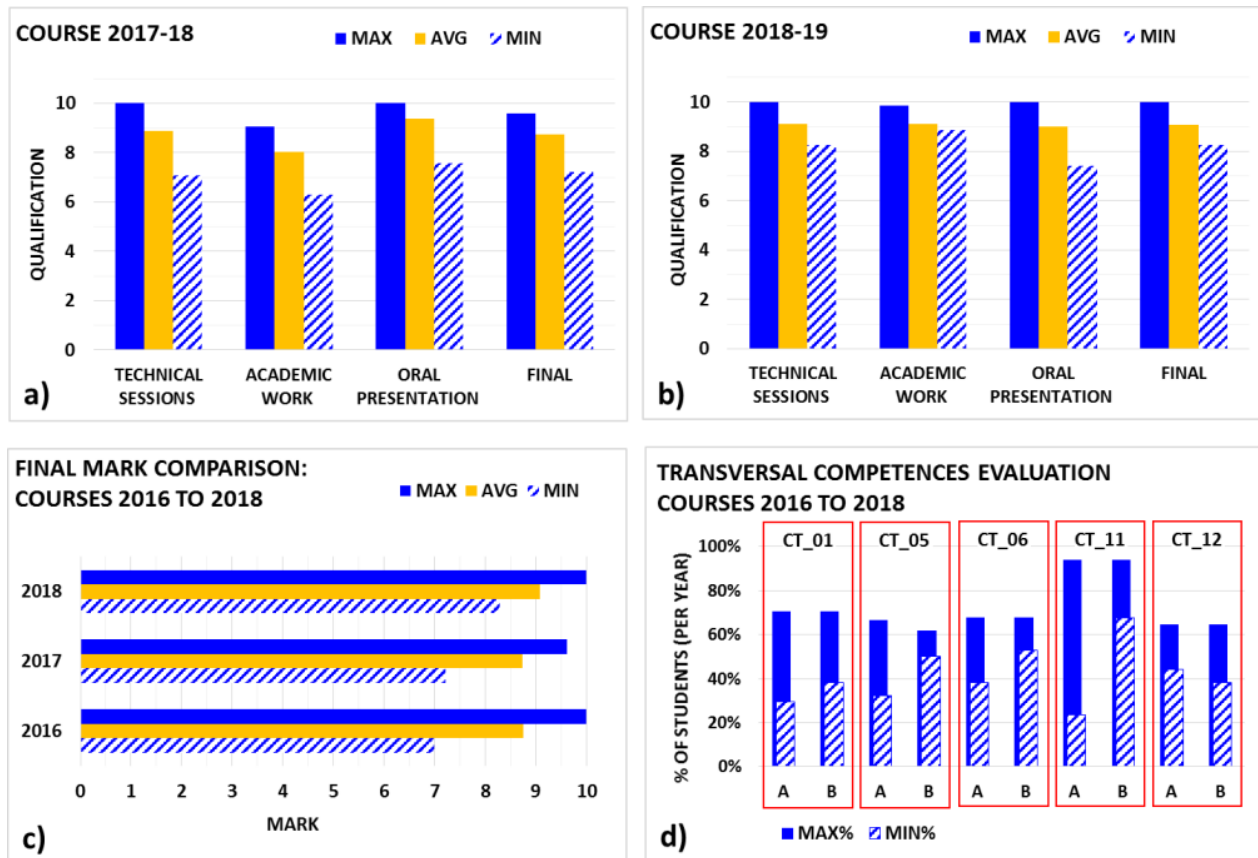

COURSES 2016 TO 2018

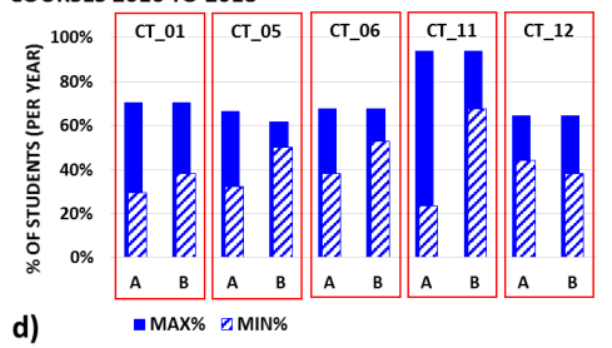

Fig. 2 AETP students assessment and transversal competences evaluation results. 
Regarding the tranversal competences evaluation, it was observed in the data that $95 \%$ of students obtained a qualification of A or B for any of the transversal competences analysed. Therefore Fig. 2.d takes only into consideration those students with A and B qualification, and presents the minimum and maximum percentages for the three courses analysed and for each tranversal competence. So it can be concluded that the competences evaluation methodology was adequate or excellent in most cases (about 30-70\% of students obtained a qualification of $\mathrm{A}$, depending on the transversal competence). Transversal competences evaluation didn't show any specific trend for last three courses. It was also noticed that students with better transversal competences evaluations usually obtained better final marks in the subject. Regarding the evaluation of the subject carried out by the students, very positive results were obtained, observing a progressive teaching quality improvement with an initial value of 7.8 out of 10 (in course 2016-2017) to 8.6 in 2018-19. This was also confirmed by internal coordination meetings with students were it was also concluded that the key elements to motivate the students were the open-door presentations, the competition between teams and the "company" approach.

\section{Conclusions}

This paper presents the description, planning, teaching methodology and experience after 4 years of teaching (courses 2015-2016 to 2018-2019) of a subject titled "Applied energy technology - Project course" (AETP) belonging to the Master in Energy Technology for Sustainable Development (MUTEDS) at the Polytechnic University of Valencia (UPV).

Very good and consistent results in students assessment, tranversal competences evaluation and students feedback were obtained. During the last three courses, a progressive improvement in these results was observed.

The fact that students had to work in a simulacrum of real situations such as being members of a multidisciplinary group inside a company that has to carry out a project, and make an oral presentation in competition with other companies, was a key motivation element for the students and it was reflected in the final marks. This, together with the teamworking sessions, resulted in a very useful tool to evaluate tranversal competences.

\section{References}

García Manjón, J., Pérez López, M.d.C., (2008). Espacio Europeo de Educación Superior: competencias profesionales y empleabilidad. Revista Iberoamericana de Educación, Vol. 46, N . 9, 2008. 46. 
Pérez Gómez, A.I. (2007) Las Competencias Básicas: su naturaleza e implicaciones pedagógicas, Cuaderno de Educación n ${ }^{\circ} 1$.

Yániz, C. (2008). Las competencias en el currículo universitario: implicaciones para diseñar el aprendizaje y para la formación del profesorado. Red U. Revista de Docencia Universitaria, número monográfico $1^{\circ}$.

Robledo, P., Fidalgo, R., Arias, O., Álvarez, M.L., (2015). Percepción de los estudiantes sobre el desarrollo de competencias a través de diferentes metodologías activas. Revista de Investigación Educativa, 33(2), 369-383.

Master in Energy Technology for Sustainable Development. (2019, February, 19) Retrieved from https://www.upv.es/titulaciones/MUTEDS/.

Johnson, Eli (2013). The Student Centered Classroom: vol 1: Social Studies and History. Ed. Taylor \& Francis Group.

Cano-Garcia, M. E. (2008) La evaluación por competencias en la educación superior. Profesorado. Revista de currículum y formación del profesorado, 2008, 12 (3).

Biggs, J. (2000) Teaching for Quality Learning at University. SRHE and Open University Press Reprint, 2000, 86-158. 